\title{
Effects of Pre-sintered Granules on the Characteristics of Porous Zirconia
}

\author{
Eun-Jung Lee, Jang-Hoon Ha*, Yang-Do Kim ${ }^{*}$, and In-Hyuck Song* ${ }^{*} \dagger$ \\ School of Materials Science and Engineering, Pusan National University, Busan 609-735, Korea \\ *Powder \& Ceramics Division, Korea Institute of Materials Science, Changwon 642-831, Korea \\ (Received May 30, 2012; Revised July 3, August 7, 2012; Accepted August 8, 2012)
}

\section{가소결된 그레뉼이 다공질 지르코니아 세라믹스의 특성에 미치는 영향 \\ 이은정 · 하장훈* · 김양도* 송인혁*† \\ 부산대학교 재료공학부 \\ *한국기계연구원 부설 재료연구소 분말/세라믹연구본부 \\ (2012년 5월 30일 접수 ; 2012년 7월 3일, 8월 7일 수정 ; 2012년 8월 8일 채택)}

\begin{abstract}
Porous zirconia ceramics are widely considered to be important due to their unique properties and potential applications. In this paper, we propose a novel approach to produce porous zirconia ceramics. The linear shrinkage of the prepared porous zirconia ceramics could be controlled to $4 \%$ by incorporating pre-sintered zirconia granules and hollow polymeric spheres. We also investigated the effect of pre-sintered zirconia granules on the microstructure and the properties, such as the porosity, pore distribution, and bending strength of the porous zirconia ceramics.
\end{abstract}

Key words : Zirconia, Microcellular ceramics, Spray dry, Hollow microsphere, Porous

\section{1. 서 론}

지르코니아 $\left(\mathrm{ZrO}_{2}\right)$ 는 대표적인 고강도 고인성 세라믹스 로서 부분안정화 지르코니아(partially stabilized zirconia, $\mathrm{PSZ}$ )와 준안정화 지르코니아 다결정체(tetragonal zirconia polycrystals, TZP) 등이 있다. 이들은 순수한 지르코니아 에 안정화제로 $\mathrm{Y}_{2} \mathrm{O}_{3}, \mathrm{CaO}, \mathrm{MgO}, \mathrm{CeO}_{2}$ 등을 첨가하여 제 조되고 있으며 특히 소결온도가 상대적으로 낮고 제조공 정이 비교적 간단한 $\mathrm{TZP}$ 가 기능성 및 구조용 세라믹스로 다양하게 사용되고 있다. ${ }^{1,2)}$ 이와 같은 지르코니아는 압전 소자, 연료전지, 광통신용 등 전자 재료와 setter 소재, 반 도체 치구 소재 등 구조 재료로서 다양한 산업용 응용분 야를 가지고 있다. ${ }^{3-7)}$ 특히, 최근 들어 밀도가 높은 지르 코니아 소재 $\left(6.0 \mathrm{~g} / \mathrm{cm}^{3}\right)$ 는 다공질화를 통하여 원가 절감 뿐만 아니라 경량화 및 통기성 향상 등을 통하여 새로운 응용분야를 창출하고 있다. ${ }^{8)}$

${ }^{\dagger}$ Corresponding author : In-Hyuck Song

E-mail : sih1654@kims.re.kr

Tel : +82-55-280-3534 Fax : +82-55-280-3392

Corresponding author : Yang-Do Kim

E-mail : yangdo@pusan.ac.kr

Tel : +82-51-510-2478 Fax : +82-51-512-0528
다공질 지르코니아 세라믹스는 높은 융점과 우수한 내 부식성으로 인하여 내화물, 산소센서, 고온 구조재료 등 으로 응용되어왔다. 특히 고강도, 내화학성 및 내마모성 뿐만 아니라 우수한 생체친화성으로 인해 생체구조 재료 로서도 응용이 기대되고 있다. ${ }^{9,10)}$

다공질 재료는 $15 \% \sim 95 \%$ 의 체적이 기공으로 이루어진 재료의 총칭으로, 기존의 치밀한 재료가 갖지 못하는 분 리, 저장, 열차단 특성을 가지고 있기 때문에 치밀한 재 료와 더불어 산업적 중요성이 증대되고 있다. 다공질 재 료 제조 기술은 크게, 재료 내부에 개기공을 도입하여 여 과/분리 효과를 얻는 기술과 개기공/폐기공의 크기, 형상, 배향, 분포 등을 제어하여 기존 재료가 갖지 못하는 새로 운 특성을 창출하는 기술로 분류할 수 있다. 이와 같은 기공 특성은 다공질 소재의 강도, 파괴 거동, 열충격 저 항성 등의 구조적 특성과 물질투과 특성, 생체적 특성 등 의 기능적 특성에 영향을 미친다. ${ }^{11-14)}$

초기 입자 크기 및 입자 분포는 세라믹의 소결과정에 서 매우 중요한 역할을 하는 것으로 보고되고 있다. ${ }^{15)}$ 즉 입자가 작아지면 그 표면 에너지는 상당히 커지게 되어 치밀화는 될 수 있으나 정전기적인 인력에 의하여 응집 이 매우 심하게 일어나게 되고 소결 수축 현상이 활발해 지게 된다. 그러나 이와 같은 높은 소결 수축 현상은 형 
상이 삼차원적으로 복잡하거나 크기가 대형인 구조 재료 를 제조하는 데 많은 문제점을 발생시킨다. 그러므로 수 축율의 최소화 및 이의 조절은 매우 중요하다.

본 실험에서는 spray dry 공정을 통하여 제조된 그레뉼 을 가소결한 지르코니아 분말과 미분체 지르코니아 분말 을 사용하여 혼합비율 변화를 통하여 지르코니아의 수축 율을 제어하고자 하였다. $1480^{\circ} \mathrm{C}$ 에서 가소결하여 사용한 spray dry된 지르코니아 분말의 함량 증가와 소결온도 변 화에 따라 강도 및 기공율에 미치는 영향을 고찰하였다. 또한 기공형성제로 속이 비어있는 중공형 미세구(hollow micorosphere)를 사용하여 내부에 구형 기공을 형성하였 으며, 기공형성제 첨가 유무에 따른 기공 구조가 기계적 강도에 미치는 영향을 고찰하였다.

\section{2. 실험 방법}

본 실험에 사용된 원료 분말은 분무건조 공정을 통하 여 제조된 그레뉼의 지르코니아 분말 $(<60 \mu \mathrm{m}$, HWYA2SDY, Guang Dong Huawang, China)과 미분체 지르코니
아 분말 $(<0.5 \mu \mathrm{m}$, HWYA-2, Guang Dong Huawang, China)을 사용하였으며, 원료 분말의 특성은 Table 1에 나타 내었다. Spray dry 공정으로 형성된 그레뉼의 경우 $2^{\circ} \mathrm{C} / \mathrm{min}$ 의 속도로 $900^{\circ} \mathrm{C}$ 까지 승온한 후, $1^{\circ} \mathrm{C} / \mathrm{min}$ 의 속도로 승온하 여 $1480^{\circ} \mathrm{C}$ 에서 2.5 시간 동안 대기 분위기에서 가소결하 여 사용하였다.

기공형성제로는 직경이 $80 \mu \mathrm{m}$ 이며, 밀도가 $0.025 \mathrm{~g} / \mathrm{cm}^{3}$ 인 중공형 미세구(hollow microsphere, 092DET80, Expancel, (Sundsvall, Sweden)를 사용하였다. 중공형 미세구는 속이 비어있는 형태로서 poly-methylmethacrylate 성분으로 이루 어져 있다.

원료 조합비는 Table 2에 나타내었으며, 칭량된 분말은 습식으로 혼합하고 용매는 증류수를 사용하였다. 가소결 된 지르코니아 그레뉼과 미분체 지르코니아 분말의 혼합 은 교반기를 이용하여 1 시간 동안 혼합 하였으며, 기공형 성제 첨가시 혼합은 가소결된 지르코니아 그레뉼과 미분 체 지르코니아 분말의 1 차 혼합 슬러리에 기공형성제인 중공형 미세구를 넣어 교반기에 1 시간 동안 2 차 혼합하였 다. 기공형성제는 지르코니아 대비 부피비 $50 \mathrm{vol} \%$ 이며, 이

Table 1. Specifications of as-received Zirconia Powder and Spray Dried Zirconia Granule

\begin{tabular}{ccccccccccc}
\hline & $\mathrm{ZrO}_{2}+\mathrm{HfO}_{2}$ & $\mathrm{SiO}_{2}$ & $\mathrm{Fe}_{2} \mathrm{O}_{3}$ & $\mathrm{Na}_{2} \mathrm{O}$ & $\mathrm{TiO}_{2}$ & $\mathrm{Cl}^{-}$ & $\mathrm{Y}_{2} \mathrm{O}_{3}$ & $\mathrm{D} 50 \mathrm{um}$ & $\mathrm{BET}\left(\mathrm{m}^{2} / \mathrm{g}\right)$ \\
\hline HWYA-2 & $>94.0$ & $<0.015$ & $<0.005$ & $<0.005$ & $<0.005$ & $<0.02$ & 5.25 & 0.443 & 8.82 \\
HWYA-2SDY & $>94.0$ & $<0.015$ & $<0.005$ & $<0.005$ & $<0.005$ & $<0.02$ & 5.25 & 61.58 & 8.94 \\
\hline
\end{tabular}

Table 2. Batch Composition of Zirconia Ceramics

\begin{tabular}{|c|c|c|c|c|}
\hline \multirow{2}{*}{ Designation } & \multicolumn{2}{|c|}{ Mixing Ratio (wt\%) } & \multirow{2}{*}{$\begin{array}{l}\text { Hollow Microsphere } \\
\text { (wt } \%, \text { vol } \%)\end{array}$} & \multirow{2}{*}{$\begin{array}{c}\text { Sintering } \\
\text { Temperature }\left({ }^{\circ} \mathrm{C}\right)\end{array}$} \\
\hline & pre-sintered $\mathrm{ZrO}_{2}$ granule & fine $\mathrm{ZrO}_{2}$ powder & & \\
\hline $1-1$ & 0 & 100 & & \\
\hline $1-2$ & 20 & 80 & & \\
\hline $1-3$ & 40 & 60 & 0 & 1480 \\
\hline $1-4$ & 60 & 40 & & \\
\hline $1-5$ & 80 & 20 & & \\
\hline $2-1$ & 0 & 100 & & \\
\hline $2-2$ & 20 & 80 & & \\
\hline $2-3$ & 40 & 60 & $0.42,50$ & 1480 \\
\hline $2-4$ & 60 & 40 & & \\
\hline $2-5$ & 80 & 20 & & \\
\hline $3-1$ & 0 & 100 & & \\
\hline $3-2$ & 20 & 80 & & \\
\hline $3-3$ & 40 & 60 & $0.42,50$ & 1530 \\
\hline $3-4$ & 60 & 40 & & \\
\hline $3-5$ & 80 & 20 & & \\
\hline $4-1$ & 0 & 100 & & \\
\hline $4-2$ & 20 & 80 & & \\
\hline $4-3$ & 40 & 60 & $0.42,50$ & 1580 \\
\hline $4-4$ & 60 & 40 & & \\
\hline $4-5$ & 80 & 20 & & \\
\hline
\end{tabular}


는 무게비로 $0.42 \mathrm{wt} \%$ 이다. 혼합된 슬러리는 필터프레싱 공정에 의해 직경 $60 \mathrm{~mm}$ 크기의 원판 형태로 $0.2 \mathrm{MPa}$ 의 압력으로 일축가압 성형하였다. 그 후에 건조된 성형체 는 전기로에서 $2^{\circ} \mathrm{C} / \mathrm{min}$ 의 속도로 $900^{\circ} \mathrm{C}$ 까지 승온한 후, $1^{\circ} \mathrm{C} / \mathrm{min}$ 의 속도로 $1480 \sim 1580^{\circ} \mathrm{C}$ 까지 승온하여 2.5 시간 동 안 대기 분위기에서 소결하였다.

지르코니아 세라믹스의 밀도는 부피와 질량을 측정하 여 계산하였으며, 전체 기공도는 측정된 밀도와 지르코니 아 세라믹스의 이론밀도로부터 계산하였다. 또한 기공의 분포는 수은 함침법을 이용한 porosimeter (AutoPore IV Series, USA)를 이용하여 측정하였으며, 기공구조는 주사 전자현미경(Scanning Electron Microscope, Jeol, Japan)을 사용하여 관찰하였다. X선 회절 pattern은 Rigaku사의 $\mathrm{XRD}$ (Horizontal X-ray Diffractomete, Japan)를 사용, 주사 영역 $20^{\circ} \sim 80^{\circ}(2 \theta)$, 주사 속도 $0.05^{\circ}[2 \theta / \mathrm{sec}]$ 의 조건에서 얻었다. 다공질 지르코니아 세라믹스의 곡강도는 시편의 크기를 $5 \mathrm{~mm} \times 5 \mathrm{~mm} \times 35 \mathrm{~mm}$ 로 제작하여, span $25 \mathrm{~mm}$ 의 치구를 사용하여 $0.5 \mathrm{~mm} / \mathrm{min}$ 의 crosshead 속도로 조건별 5 개의 시편으로 3점 곡강도를 측정하였다.

\section{3. 결과 및 고찰}

\section{1. 지르코니아 분말의 혼합비율 변화 및 기공형성제 첨 가에 따른 영향}

분무건조(spray dry) 공정을 통하여 제조된 그레뉼의 원 료분말 Fig. 1(a)과 $1480^{\circ} \mathrm{C}$ 에서 가소결한 지르코니아 분 말을 Fig. 1(b)에 나타내었다. 가소결 후에도 그레뉼들이 스프레이 공정 특유의 원형을 그대로 유지하는 것을 볼 수 있다. 또한 가소결 공정중에 그레뉼 분말이 응집이 일 어나지 않았음을 가소결 분말의 유동성 평가 및 미세구 조 관찰을 통하여 확인하였다.

Fig. 2는 지르코니아 분말의 혼합비율 변화와 기공형성 제 첨가 유무에 따른 소결 시편의 파단면 조직사진이다. Fig. 2 좌측의 그림은 중공형 미세구가 첨가되지 않은 상 태에서 가소결된 지르코니아 그레뉼의 함량 변화에 따른 미세구조를 관찰한 사진이다. 가소결된 지르코니아 그레 뉼이 $40 \mathrm{wt} \%$ 첨가 시 까지는 미분체 지르코니아 분말들 이 가소결된 지르코니아 그레뉼들을 둘러싸고 있어 원형 의 가소결된 지르코니아 그레뉼들의 형상이 보이지 않는 것을 볼 수 있으며 $60 \mathrm{wt} \%$ 첨가 시 일부 원형의 형상이 나타나는 것을 볼 수 있다. 그러나 가소결된 지르코니아 그레뉼의 함량이 $80 \mathrm{wt} \%$ 첨가 시 미분체 지르코니아 분 말들이 충분히 가소결된 지르코니아 그레뉼들을 둘러싸지 못하여 원형의 가소결된 지르코니아 그레뉼들이 거의 그 대로 보이는 것을 볼 수 있고 입자들 사이가 치밀하지 못 한 것을 관찰할 수 있다.

Fig. 2 우측의 그림은 중공형 미세구가 $50 \mathrm{vol} \%$ 첨가된
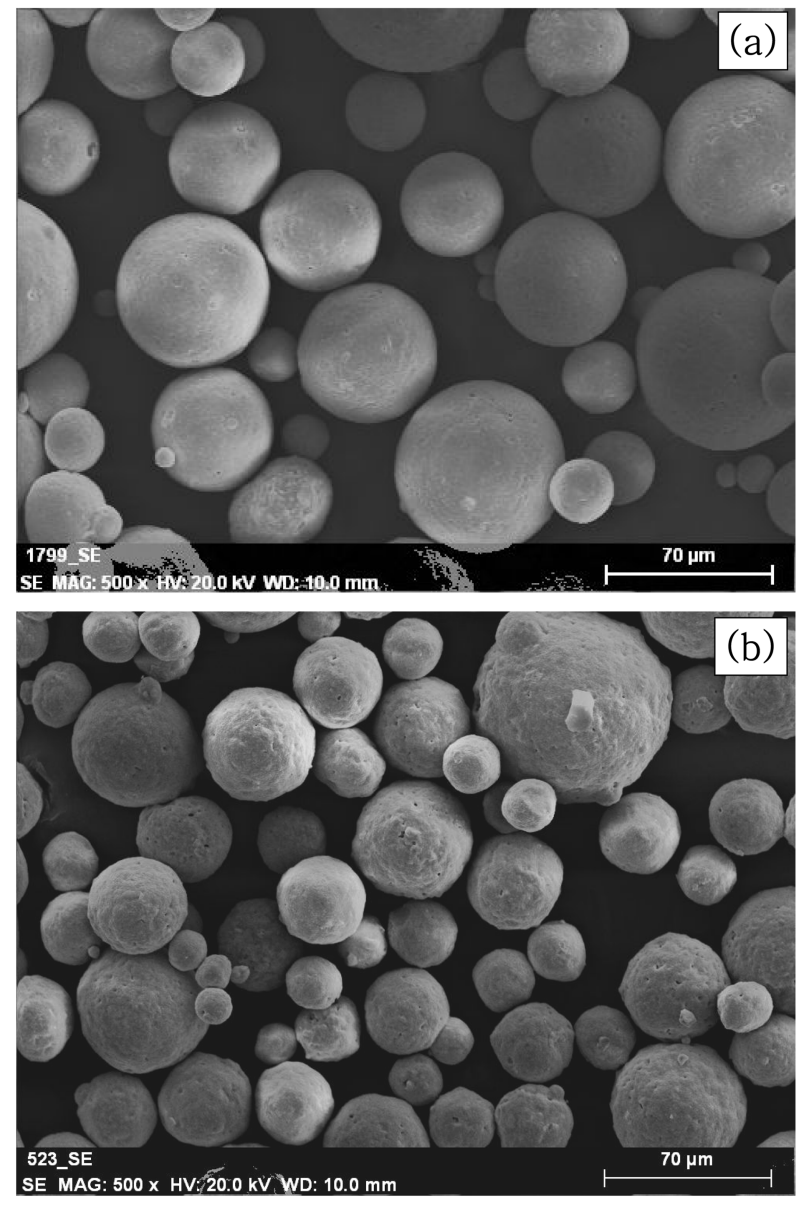

Fig. 1. SEM images of (a) spray-dried zirconia granules and (b) spray-dried zirconia granules after pre-sintering at $1480^{\circ} \mathrm{C}$ for $2.5 \mathrm{~h}$.

상태에서 가소결된 지르코니아 그레뉼의 함량 변화에 따 른 미세구조를 관찰한 사진이다. 기공형성제인 중공형 미 세구의 첨가에 따라 가소결된 지르코니아 그레뉼의 함량 과 상관없이 구형의 기공구조가 잘 형성되어 있는 것을 관찰할 수 있으며, 이는 전형적인 마이크로셀룰라 세라믹 스의 미세조직으로 기공간의 네트워크를 구성하고 있음 을 확인할 수 있다. 기공형성제인 중공형 미세구의 크기 가 $80 \mu \mathrm{m}$ 이므로 Fig. 2 의 파단면 상의 기공 크기와 거의 일치함을 관찰할 수 있었다.

Fig. 3은 가소결된 지르코니아 그레뉼의 함량 변화에 따 른 밀도 변화를 중공형 미세구의 첨가 여부에 따라 고찰 한 것이다. Fig. 3(a)는 밀도 변화를 나타낸 것으로서 가 소결된 지르코니아 그레뉼의 함량이 증가함에 따라 밀도 가 감소하는 경향을 보여 주고 있다. 이는 조대한 가소결 된 지르코니아 그레뉼의 함량이 증가함에 따라 소결성이 저하되기 때문이다. 또한 기공형성제인 중공형 미세구가 첨가됨에 따라서 낮은 밀도 값을 보여 주었다. Fig. 3(b) 는 상기의 시편의 수축율의 변화를 나타낸 것으로 가소 


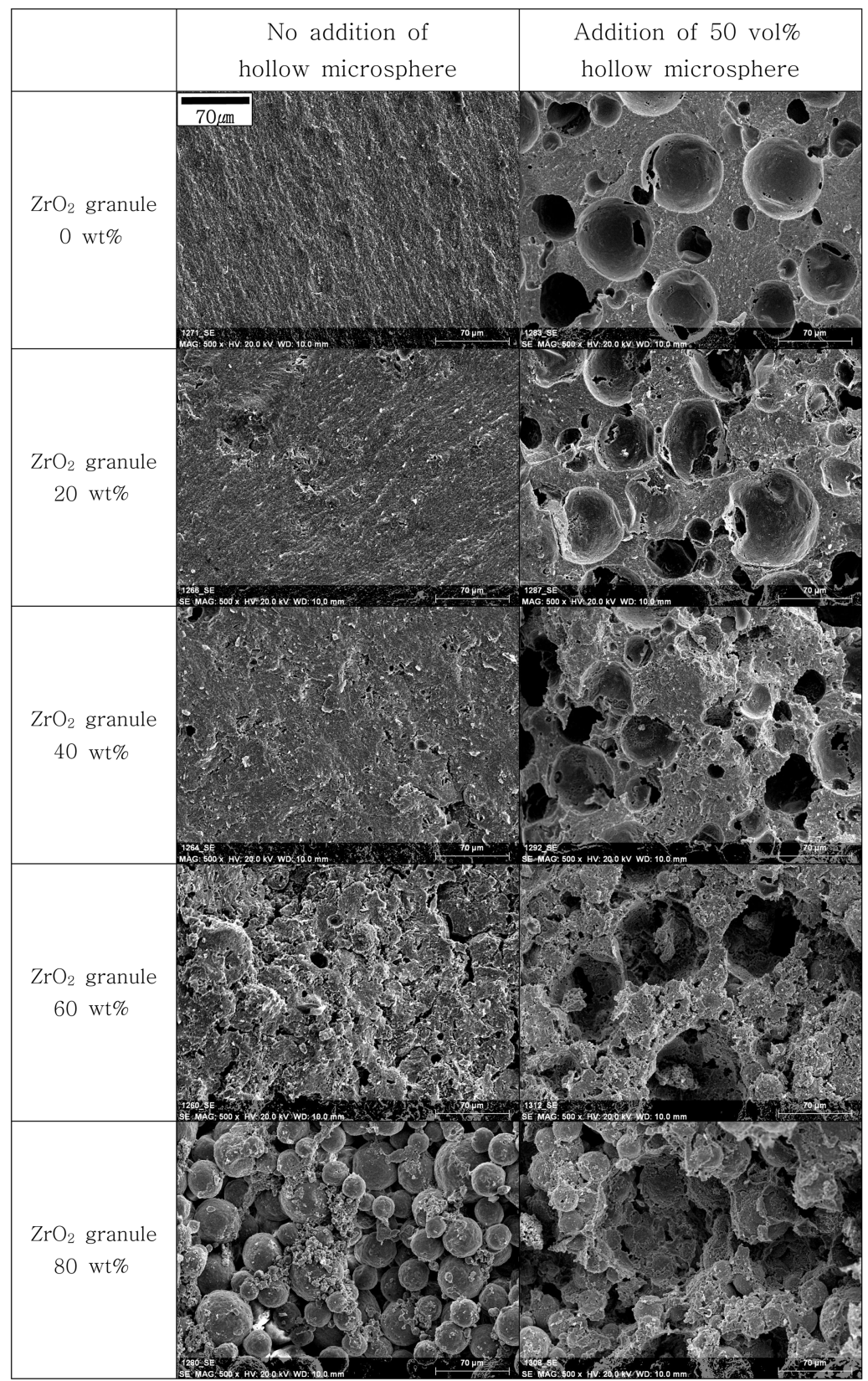

Fig. 2. SEM images of porous zirconia ceramics sintered at $1480^{\circ} \mathrm{C}$ for $2.5 \mathrm{~h}$ with increasing amount of pre-sintered zirconia granules.

결된 지르코니아 그레뉼의 첨가량이 증가함에 따라 수축 율이 $20 \%$ 내외에서 $5 \%$ 내외로 급격히 감소하는 것을 관 찰할 수 있다. 이는 다공성 지르코니아의 대형 기물 제작 에 걸림돌이 되는 높은 수축율 억제에 가소결된 지르코 니아 그레뉼의 첨가는 매우 효과적인 것으로 판단된다. Onoda 등 ${ }^{16-19)}$ 에 의하면 2원계 혼합분말에서 큰 입자의 함량이 많아질수록 소결 수축율은 적어지는데, 작은 입자 들은 큰 입자들의 공극(interstice)에 존재하게 되므로 작 은 입자들의 수축은 있는 반면에 전체적인 수축은 큰 입 자들이 접촉하고 있을 때까지 일어나므로 수축율이 크지
않다. 반면 작은 입자가 많을 경우에는 큰 입자들 주위에 작은 입자들이 존재하여 작은 입자들이 수축에 의존하여 큰 입자들 간의 접촉이 있을 때 보다 큰 수축율을 나타낸 다. 이는 본 실험의 결과와도 일치하는 결과를 보여 주고 있다.

Fig. 4는 기공형성제가 첨가된 지르코니아 분말의 혼합 비율 변화에 따른 기공율 변화를 나타낸 것이다. 기공율 변화는 이론밀도를 사용하여 시편의 부피와 질량비를 계 산한 기공율을 총기공율(total prosity)로 계산하여 나타내 었으며, 수은 함침법을 사용하여 함침된 수은의 양으로 


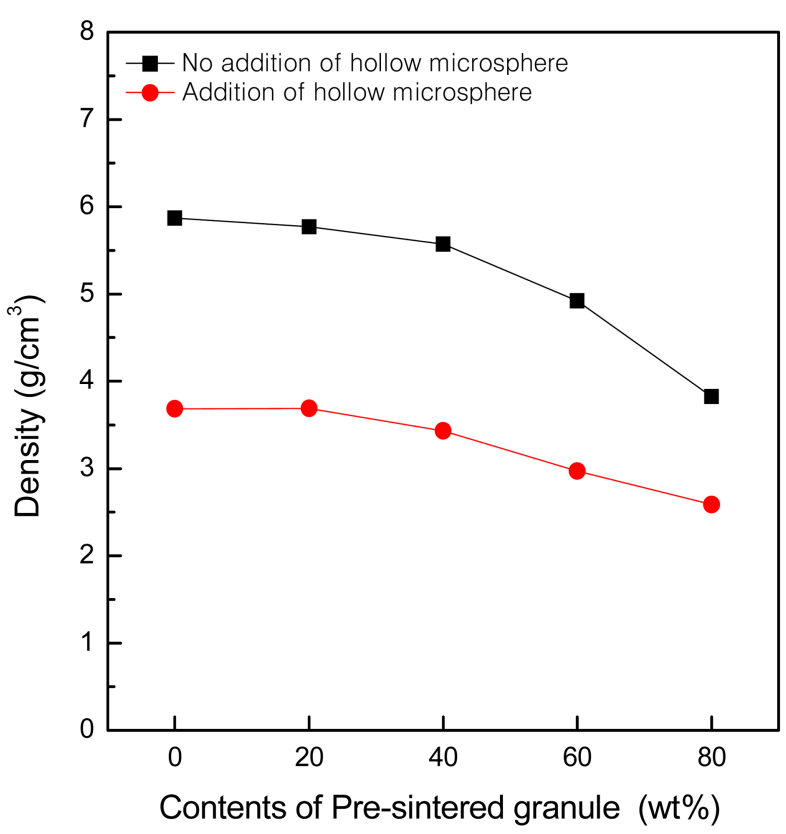

(a)

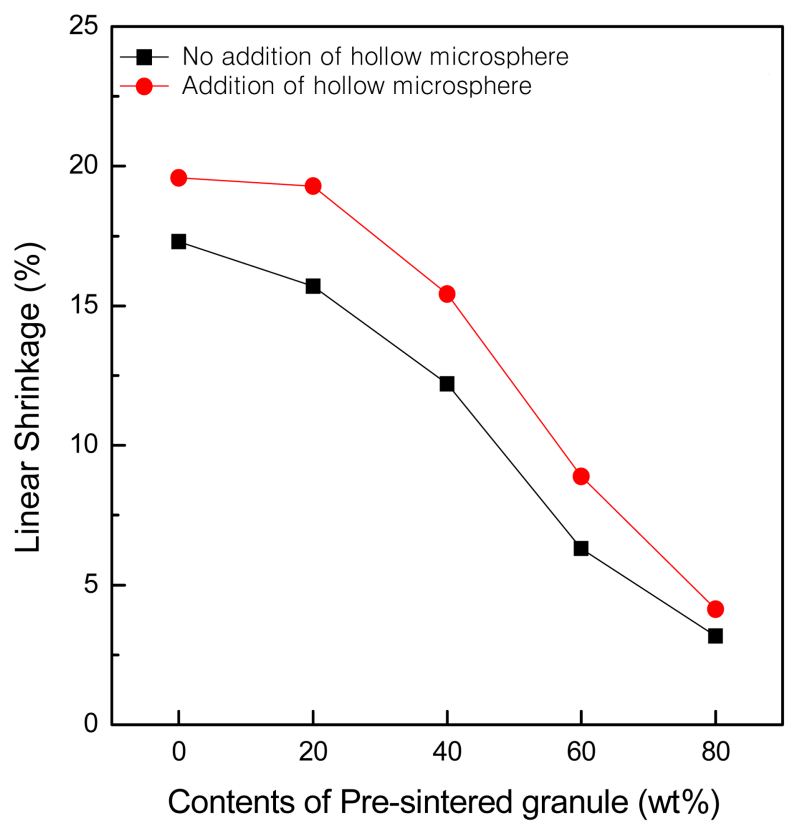

(b)

Fig. 3. (a) Density and (b) linear shrinkage of porous zirconia ceramics sintered at $1480^{\circ} \mathrm{C}$ for $2.5 \mathrm{~h}$ with the amount of pre-sintered granule and hollow microsphere.

계산된 기공율은 개기공율(open porosity)로 나타내었다. 이는 총기공율과 개기공율의 차를 폐기공율로 정의할 수 있다. 전체적인 기공율의 변화 측면에서 살펴보면 가소결 된 지르코니아 그레뉼의 양이 증가함에 따라 기공율이 비 례하여 증가하는 것을 볼 수 있으며, 이는 Fig. 3(a)의 밀 도 변화와 일치하는 경향을 보여주고 있다. 또한 가소결 된 지르코니아 그레뉼의 양이 증가할수록 개기공의 양이

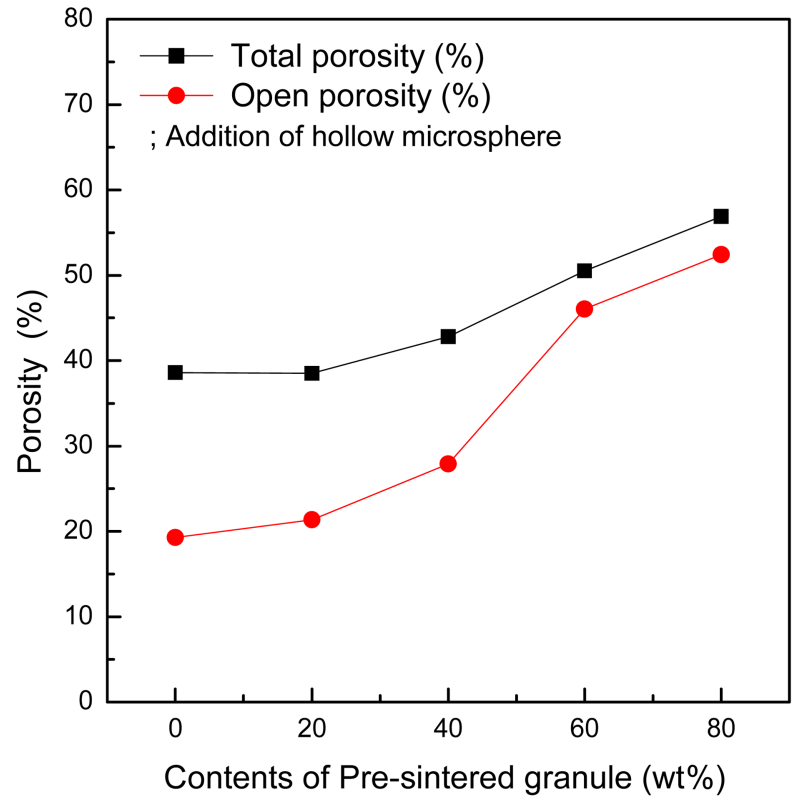

Fig. 4. Total porosity and open porosity of porous zirconia ceramics sintered at $1480^{\circ} \mathrm{C}$ for $2.5 \mathrm{~h}$ with pre-sintered granule contents and addition of hollow microsphere.

증가되는 것을 볼 수 있는데, 동일한 기공형성제가 첨가 되었음에도 기공율의 차이를 보이는 것은 가소결된 지르 코니아 그레뉼의 양이 증가함에 따라 치밀화율이 저하되 어 기공구조가 폐기공에서 개기공으로 전환되어 나타나 는 경향으로 보인다. 이와 같은 연구 결과는 치밀한 재료 에서는 부정적인 연구 결과이나 다공질 재료에서 개기공 으로의 전환은 향후 다양한 분리/여과/반응의 용도로 사 용하기에 적합할 것으로 판단된다.

Fig. 5는 수은 함침법을 이용하여 기공형성제가 첨가된 지르코니아 분말의 혼합비율 변화에 따른 기공크기 분포 를 측정한 결과이다. 전반적으로 가소결된 지르코니아 그 레뉼의 양이 증가할수록 수은의 함침량(피크의 단면적) 은 증가하는 것을 볼 수 있으며 이는 정량적인 개기공 의 양이 증가함을 나타낸 것이다. 또한 가소결된 지르코 니아 그레뉼의 양이 증가할수록 기공의 크기는 $2.6 \mu \mathrm{m} \sim$ $21.9 \mu \mathrm{m}$ 로 증가하는 것을 볼 수 있으며, 기공형성제인 중 공형 미세구의 크기 $80 \mu \mathrm{m}$ 이므로 측정된 기공크기가 중 공형 미세구에 의해 형성된 셀 크기가 아니라, 셀과 셀 사이를 연결시켜주는 개기공이 측정된 결과를 의미한다. 즉 셀과 셀 사이의 연결 경로를 따라서 액체 수은이 조 대한 구형 기공으로 침투되어 측정되었기 때문이다. 따 라서 Fig. 5와 같이 가소결된 지르코니아 그레뉼의 양이 많이 첨가된 시편이 개기공이 발달하여 기공의 크기도 커진 것을 알 수 있다.

Fig. 6은 지르코니아 분말의 혼합비율 변화와 기공형성 제 첨가 유무에 따른 곡강도 실험 결과로서, 기공함량이 높을수록 강도가 낮아지는 일반적인 경향을 볼 수 있다. 
Chae 등은 ${ }^{20)}<44 \mu \mathrm{m}$ 크기의 지르코니아 분말에 $20 \mu \mathrm{m}$ 크기의 기공형성제 $\mathrm{PMMA}$ 를 첨가하여 다공질 지르코니아 세라믹스를 제조하여 기공율 $~ 50 \%$ 일때 강도는 $~ 35 \mathrm{MPa}$ 을 나타내었고, Gain 등은 ${ }^{21)} 70 \mathrm{~nm}$ 크기의 지르코니아 분말에 $150 \sim 200 \mu \mathrm{m}$ 크기의 기공형성제 $\mathrm{PMMA}$ 를 첨가하여 다 공질 지르코니아 세라믹스를 제조하여 기공율 50\%일때 강도는 $\sim 180 \mathrm{MPa}$ 을 나타내었다. 상기 보고된 결과를 바

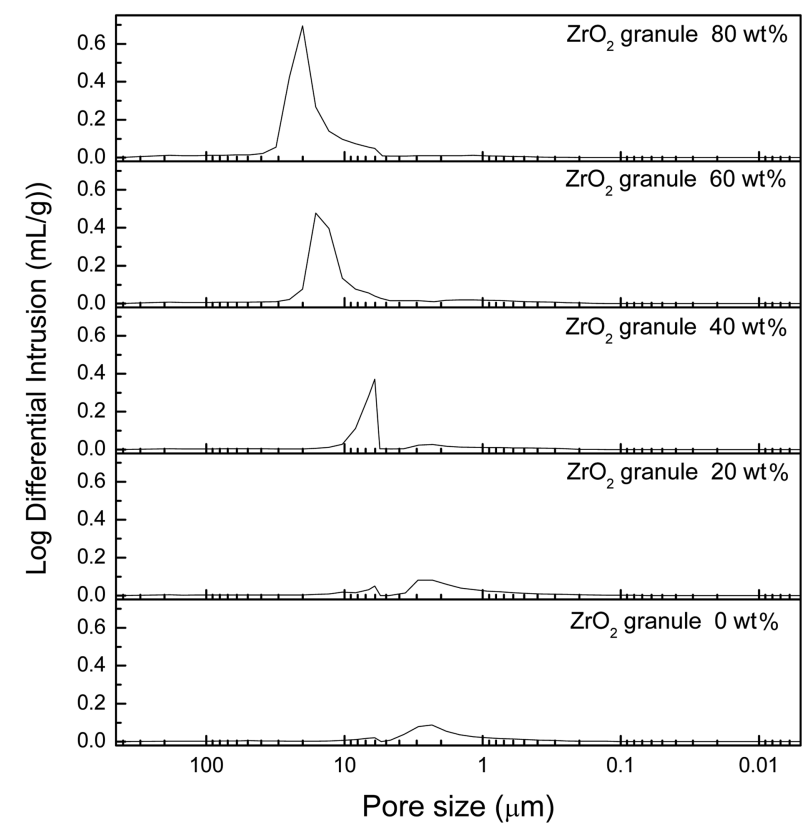

Fig. 5. Pore size distributions of porous zirconia ceramics sintered at $1480^{\circ} \mathrm{C}$ for $2.5 \mathrm{~h}$ measured by mercury porosimeter.

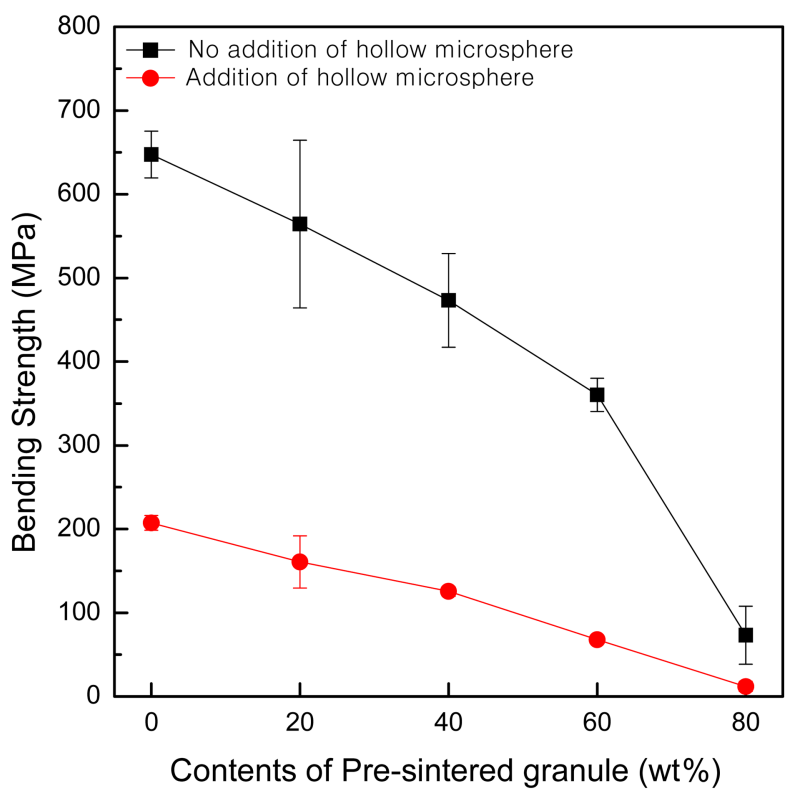

Fig. 6. Bending strength of porous zirconia ceramics sintered at $1480^{\circ} \mathrm{C}$ for $2.5 \mathrm{~h}$ with pre-sintered granule contents and addition of hollow microsphere.
탕으로 비교해 볼 때 곡강도의 차이는 출발원료의 입자 크기에도 많은 영향을 받는 것을 알 수 있다.

일반적으로 기계 구조용 소재의 기계적 강도는 사용 목 적에 따라 차이가 있으나 필터 및 단열 소재의 용도의 경 우 $50 \mathrm{MPa}$ 을 기준으로 하고 있다. 즉 최대한 개기공 구 조가 발달한 상태에서 $50 \mathrm{MPa}$ 의 고강도를 유지 하는 것 은 매우 중요하다. 본 실험에서 최적조건은 $60 \mathrm{wt} \%$ 의 그 레뉼이 첨가된 경우로서, $40 \%$ 이상의 높은 개기공율을 보여 주었으며, 기계적 강도면에서도 중공형 미세구가 첨 가된 경우 $67 \mathrm{MPa}$, 중공형 미세구가 첨가되지 않은 경우 $360 \mathrm{MPa}$ 의 특성 값을 보여 주었다.

또한 본 연구에서는 조대한 지르코니아 그레뉼과 미분 체 지르코니아 분말을 혼합하여 사용할 경우 조대한 그 레뉼의 함량이 증가함에 따라 기계적 특성의 감소를 피 할 수 없었다. 그러나 소결 수축률 감소 및 개기공 함량 의 증대를 통하여 기술적인 응용성을 확대시켰다고 평가 할 수 있다.

\section{2. 소결온도 변화에 따른 영향}

Fig. 7은 소결온도 변화에 따라서 기공형성제인 중공형 미세구가 첨가된 다공질 지르코니아 세라믹스의 파단면 미세구조를 관찰한 사진이다. Fig. 7의 (a), (c), (e)에서 보 듯이 소결온도에 관계없이 구형의 기공구조가 잘 발달된 경향을 볼 수 있다. 그러나 Fig. 7의 (b), (d), (f)를 보면 $1480^{\circ} \mathrm{C}$ 에서 소결한 시편의 결정크기는 작고 조밀한데 반해, $1580^{\circ} \mathrm{C}$ 에서 소결한 시편은 결정립의 성장이 일

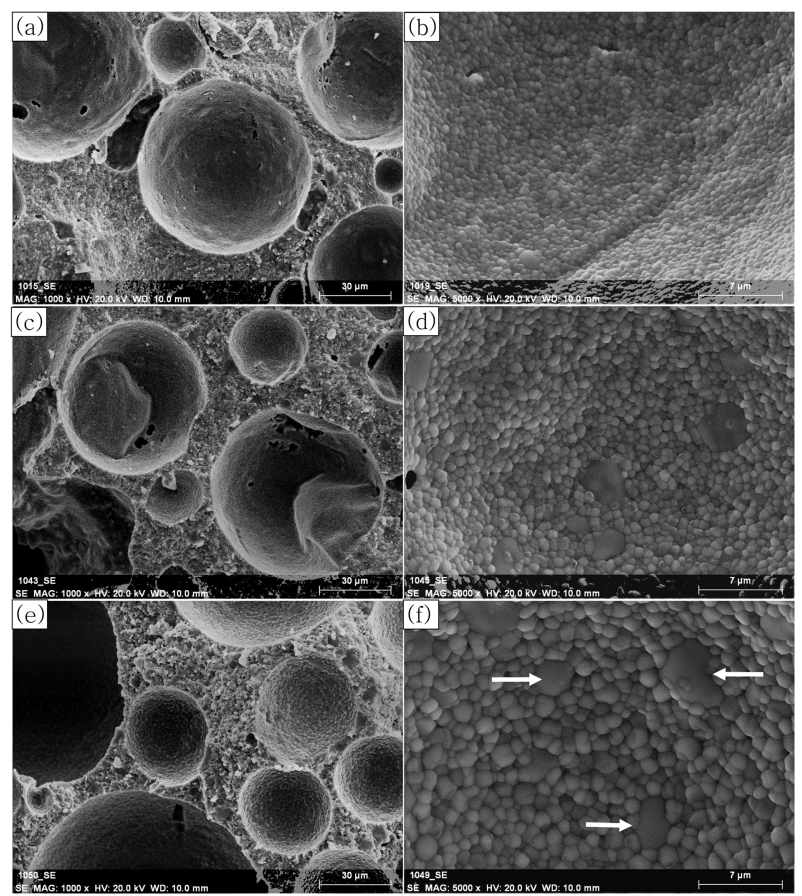

Fig. 7. SEM images of porous zirconia ceramics sintered at $1480^{\circ} \mathrm{C}((\mathrm{a}),(\mathrm{b})), 1530^{\circ} \mathrm{C}((\mathrm{c}),(\mathrm{d}))$, and $1580^{\circ} \mathrm{C}((\mathrm{e}),(\mathrm{f}))$ 


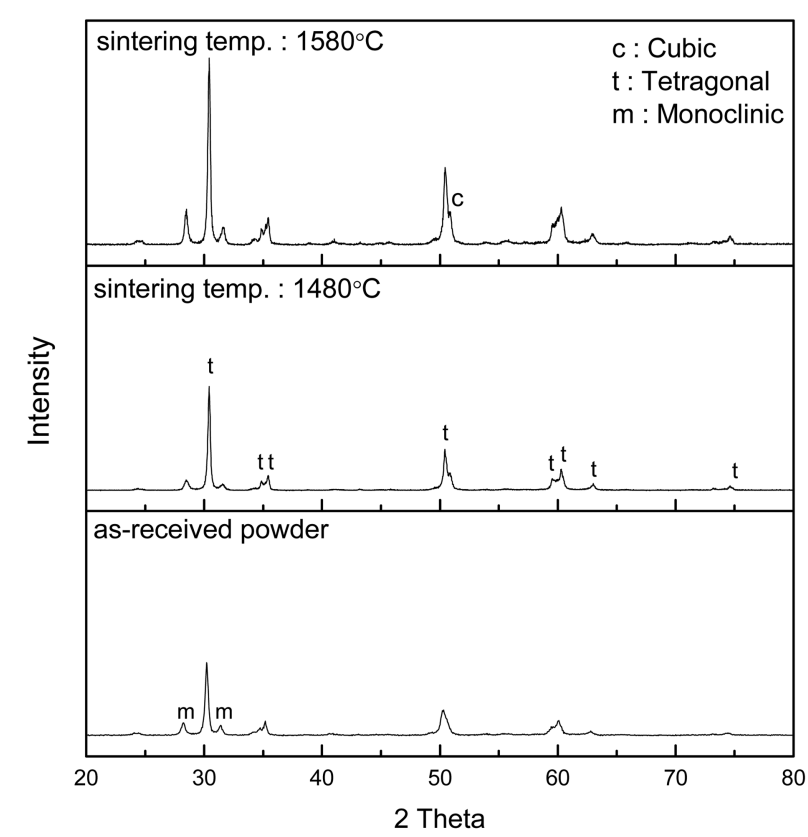

Fig. 8. XRD results of porous zirconia ceramics sintered at different temperatures.

어나 결정립이 크게 형성되어 있는 것을 볼 수 있다. 따라서 소결온도가 $1480^{\circ} \mathrm{C}$ 에서 $1580^{\circ} \mathrm{C}$ 로 증가함에 따 라 치밀화 뿐만 아니라 입자성장이 이루어진 것을 알 수 있다.

다공성 지르코니아의 소결온도 변화에 따라 측정한 $\mathrm{X}$ 선 분석 결과를 Fig. 8에 나타내었다. 본 실험에서 사용 된 지르코니아 분말은 $\mathrm{Y}_{2} \mathrm{O}_{3}$ 에 의해 안정화된 정방정 (tetragonal) 구조의 결정구조를 가지고 있다. 소결온도가 증가할수록 정방정 피크를 나타내는 intensity 값이 점점 증가하는 것을 볼 수 있으며 소결온도가 $1580^{\circ} \mathrm{C}$ 일 때에 는 입방정의 상도 볼 수 있다. Fig. 7(f)에서도 소결온도 가 $1580^{\circ} \mathrm{C}$ 일 경우 소결온도 증가로 인해 조대한 입방정 상이 국부적으로 관찰되었으며(화살표로 표시), 이는 $\mathrm{Scott}^{22-24)}$ 등의 $\mathrm{ZrO}_{2}-\mathrm{Y}_{2} \mathrm{O}_{3}$ 계 상평형도에서도 확인할 수 있다.

Fig. 9는 소결온도 변화에 따른 기공형성제가 첨가된 다공질 지르코니아 세라믹스의 밀도 및 선수축율을 나타 낸 것으로 지르코니아 혼합비율에 따른 변화는 Fig. 3과 같은 경향을 보이나 소결온도 증가에 따른 밀도와 선수 축율의 증가 경향은 크게 나타나지 않았다. 이는 소결온 도가 증가함에 따라 일반적인 분말 소결체와 같은 전체 적인 부피 축소보다는 기공 벽(strut) 조직의 치밀화 및 입자 성장이 우세하기 때문으로 판단된다.

Fig. 10은 소결온도 변화에 따라서 기공형성제가 첨가 된 다공질 지르코니아 세라믹스의 곡강도 변화를 나타낸 것으로 일반적으로 세라믹 재료의 소결온도가 증가하면 치
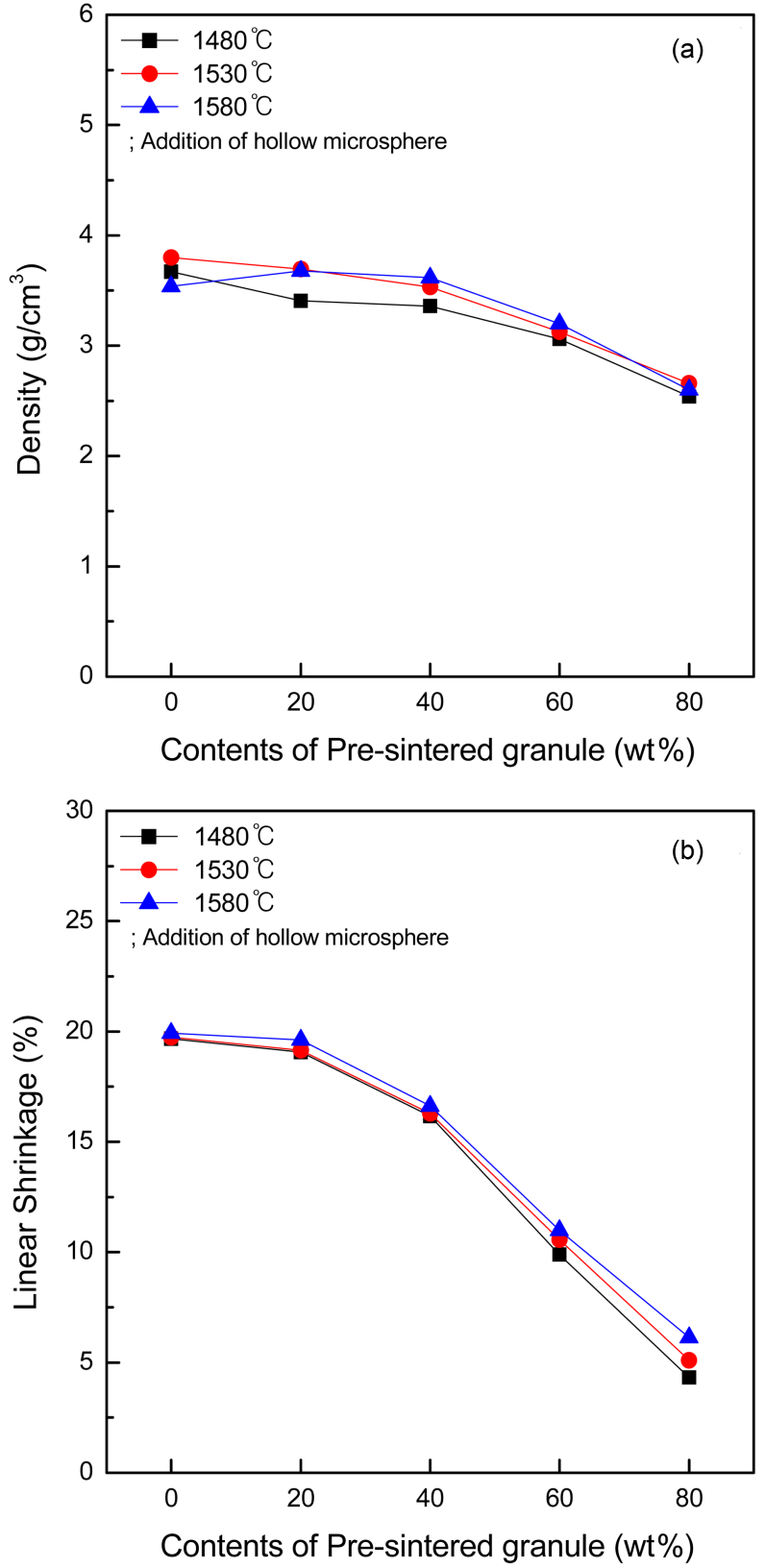

Fig. 9. (a) Density and (b) linear shrinkage of porous zirconia ceramics with the amount of pre-sintered granule and sintering temperatures.

밀화가 이루어지고 강도 증가를 유발한다. 그러나 Fig. 10 에서와 같이 소결온도의 증가에도 강도의 변화가 크지 않 는 것을 볼 수 있다. 이는 Fig. 7에서 관찰 되는 바와 같 이 온도가 증가할수록 국부적으로 입방정 상이 나타나 입 자가 조대해져 기계적 특성이 저하된 것으로 보이며 Stawarczyk $^{25)}$ 등의 결과에서도 소결 온도별로 입자 크기 가 조대화 되면 강도 변화가 없거나 점차적으로 저하되 는 경향을 나타내는 것을 확인할 수 있다. 


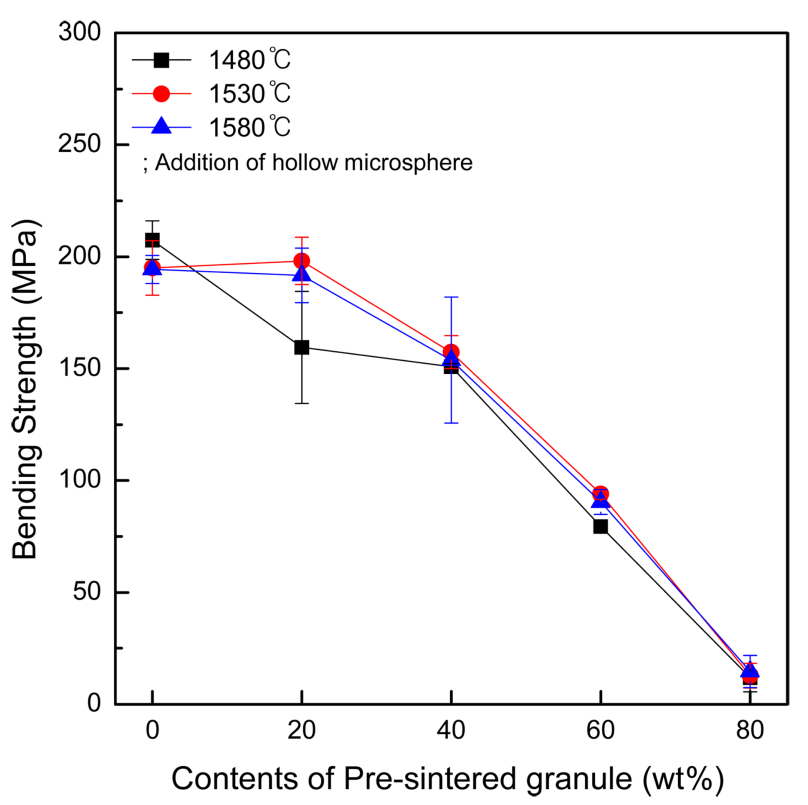

Fig. 10. Bending strength of porous zirconia ceramics with presintered granule content and sintering temperature.

\section{4. 결 론}

본 연구는 미세구조가 제어된 다공성 지르코니아를 소 결하기 위하여, 가소결된 지르코니아 그레뉼과 미분체 지르코니아 분말, 기공 형성제인 중공형 미세구를 사용 하여 원료 구성비와 소결 온도를 조절하였다. 미분체 대 비 조대한 지르코니아 분말을 얻기 위하여 spray dry 공 정을 통하여 제조된 지르코니아 그레뉼을 $1480^{\circ} \mathrm{C}$ 에서 가소결 하였다. 지르코니아 그레뉼과 미분체 지르코니 아 분말의 혼합 비율을 조절하여 수축율을 $20 \%$ 내외에 서 $5 \%$ 내외로 제어할 수 있었다. 지르코니아 그레뉼의 함량이 증가함에 따라 소결 수축율이 감소하였고, 개기 공 함량이 증대하여 다공성 지르코니아의 응용 범위를 증대시킬 수 있었다. 특히 그레뉼 함량이 $60 \mathrm{wt} \%$ 첨가 된 경우 $40 \%$ 이상의 높은 개기공율을 보여 주었으며, 기계적 강도면에서도 중공형 미세구가 첨가된 경우 $67 \mathrm{MPa}$, 중공형 미세구가 첨가되지 않은 경우 $360 \mathrm{MPa}$ 의 곡강도 값을 보여 주었다. 소결 온도를 $1480^{\circ} \mathrm{C}$ 에서 $1580^{\circ} \mathrm{C}$ 로 증가시키더라도, 정방정 입자 크기의 증가 및 국부적으로 입방정상 입자 성장으로 인하여 기계적 특 성은 큰 변화가 없었다.

\section{Acknowledgment}

본 연구는 방위사업청 및 국방과학연구소 지원으로 수 행되는 차세대 군용 전원특화연구센터 사업의 일환으로 수행되었습니다.

\section{REFERENCES}

1. G. Suarez, L. B. Garrido, and E. F. Aglietti, "Sintering Kinetics of 8Y-Cubic Zirconia: Cation Diffusion Coefficient," Mater. Chem. Phys., 110 [2-3] 370-75 (2008).

2. S. Ramanathan and S. K. Roy, "Liquid Phase Sintering of Yttria-Stabilised Zirconia," Interceram., 4 253-55 (1994).

3. M. P. Albano, L. A. Genova, L. B. Garrido, K. Plucknett, "Processing of Porous Yttria-stabilized Zirconia by Tapecasting," Ceram. Inter, 34 [8] 1983-88 (2008).

4, I. K. Jun, Y. H. Koh, J. H. Song, S. H. Lee, and H. E. Kim, "Improved Compressive Strength of Reticulated Porous Zirconia Using Carbon Coated Polymeric Sponge As Novel Template," Mater. Lett., 60 2507-10 (2006).

5. A. K. Gain and B. T. Lee, "Microstructure Control of Continuously Porous t-ZrO2 Bodies Fabricated by Multi-Pass Extrusion Process," Mater. Sci. Eng. A, 419 269-75 (2006).

6. B. Nait-Ali, K. Haberko, H. Vesteghem, J. Absi, and D. S. Smith, "Thermal Conductivity of Highly Porous Zirconia," J. Eur. Ceram. Soc., 26 3567-74 (2006).

7. A. K. Gain, H. Y. Song, and B. T. Lee, "Microstructure and Mechanical Properties of Porous Yttria Stabilized Zirconia Ceramic Using Poly Methyl Methacrylate Powder," Scripta Mater, 54 2081-85 (2006).

8. E. J. Lee, I. H. Song, H. D. Kim, Y. W. Kim, and J. S. Bae "Investigation on the Pore Properties of the Microcellular $\mathrm{ZrO}_{2}$ Ceramics using Hollow Microsphere," J. Kor. Ceram. Soc., 46 [1] 108-15 (2009).

9. D. H. Jang, K. Y. Lim, and Y.-W. Kim, "Effects of Additive Composition and Content on Sintered Density and Compressive Strength of Cordierite Ceramics(in Korean)," $J$. Kor. Ceram. Soc., 44 [4] 230-34 (2007).

10. J. H. Eom and Y.-W. Kim, "Fabrication of Silicon Oxycarbide Foams from Extruded Blends of Polysiloxane, LowDensity Polyethylene (LDPE), and Polymer Microbead," Met. Mater. Int., 13 [6] 521-25 (2007).

11. J. Saggio-Woyansky, C. E. Scott, and W. P. Minnear, "Processing of Porous Ceramics," Am. Ceram. Soc. Bull., 71 [11] 1674-82 (1992).

12. P. Sepulveda, "Gelcasting Foams for Porous Ceramics," Am. Ceram. Soc. Bull., 76 [10] 61-5 (1997).

13. I. H. Song, I. M. Kwon, H. D. Kim, and Y. W. Kim, "Processing of Microcellular Silicon Carbide Ceramics with a Duplex Pore Structure," J. Eur. Ceram. Soc., 30 [12] 267176 (2010).

14. I. H. Song, M. J. Park, H. D. Kim, Y. W. Kim, and J. S. Bae, "Microstructure and Permeability Property of Si Bonded Porous $\mathrm{SiC}$ with variations in the Carbon Content," J. Kor. Ceram. Soc., 47 [6] 546-52 (2010).

15. G. Y. Onoda, "Ceramic Processing before Firing," pp.22, Wiley \& Sons, 1978.

16. G. Y. Onoda. Jr., "Green Body Characteristics and Their Relationship to Finished Microstructure, in Ceramic Microstructures," pp. 163, Westview Press, 1977.

17. G. L. Messing and G. Y. Onoda, Jr., "Sintering of Inhomogeneous Binary Powder Mixtures," J. Am. Ceram. Soc., 
64 [8] 468-72 (1981).

18. G. L. Messing and G. Y. Onoda, Jr., "Inhomogeneity-Packing Density Relations in Binary Powders-Experimental Studies," J. Am. Ceram. Soc., 61 [7] 363-66 (1978).

19. K. B. Park, T. H. Kim, and K. H. Yoon "Initial Particle Size Effects on Sintering and Dielectric Properties of $\mathrm{Pb}\left(\mathrm{Fe}_{1 / 2}\right.$ $\left.\mathrm{Nb}_{1 / 2}\right) \mathrm{O}_{3}$," J. Kor. Ceram. Soc., 29 [9] 711-18 (1992).

20. S. H. Chae, J. H. Eom, Y.-W. Kim, I. H. Song, H. D. Kim, J. S. Bae, S. M. Na, and S. L. Kim, "Porosity Control of Porous Zirconia Ceramics," J. Kor. Ceram. Soc., 45 [1] 658 (2008).

21. A. K. Gain and B. T. Lee, "Microstructure Control of Continuously Porous $\mathrm{t}-\mathrm{ZrO}_{2}$ Bodies Fabricated by Multi-Pass Extrusion Process," Mater. Sci. Eng. A, 419 269-75 (2006).
22. H. G. Scott, "Phase Relationships in the Zirconia-Yttria System," J. Mater. Sci., 10 1527-5 (1975).

23. O. Fabrichnaya and F. Aldinger, "Assessment of the Thermodynamic Parameters in the System $\mathrm{ZrO}_{2}-\mathrm{Y}_{2} \mathrm{O}_{3}-\mathrm{Al}_{2} \mathrm{O}_{3}$," Zeit. Metall., 95 [1] 27-9 (2004).

24. J. Chevalier and L. Gremillard, A. V. Virkar, D. R. Clarke, "The Tetragonal-Monoclinic Transformation in Zirconia : Lesson Learned and Future Trends," J. Am. Ceram. Soc., 92 [9] 1901-20 (2009).

25. B. Stawarczyk, M. Ozcan, L. Hallmann, A. Ender, A. Mehl, C. H. F. Hammerle, "The Effect of Zirconia Sintering Temperature on Flexural Strength, Grain Sixe, and Contrast Ratio," Clin Oral Invest., 1-9 (2012). doi:10.1007/s00784012-0692-6. 